\title{
Successful Implementation of Information Systems in Public Sector Organizations
}

\author{
Ajeng Apridiyanti \\ Faculty of Economics and Business \\ Universitas Padjadjaran \\ Harry Suharman \\ Faculty of Economics and Business \\ Universitas Padjadjaran \\ Zaldy Ardianto \\ Faculty of Economics and Business \\ Universitas Padjadjaran
}

\begin{abstract}
This study aims to determine the success of the implementation of the Regional Financial Management Information System (SIPKD) in the Regional Work Unit (SIPKD) in the Sumedang District Government, by examining the effect of system quality, information quality and service quality on user satisfaction and its implications for net benefits. This study uses primary data from questionnaires given to leaders of agencies, operators, and administrators of SIPKD. The data analysis method used is path analysis. The results of this study indicate that the quality of the system, the quality of information, and the quality of service affect user satisfaction and impact on net benefits both partially and simultaneously. The results of this study contribute to adding literature on the implementation of information systems in public sector organizations, and influencing factors can be used as a reference for public sector organizations in assessing the application of information systems.
\end{abstract}

Keywords: System quality; Information quality; Service quality; User satisfaction; Net benefits

\section{Introduction}

Information systems have been used in companies to help their activities. The information system used must be following the needs of the company to improve the company's maximum performance. Information systems that are not developing the company's business processes, usually become a problem in the process of using an information system (Janson \& Subramanian, 1996; Lucas, Walton, Ginzberg, \& Leonard Stern, 1988). Information systems are essential in the company so that the application of information systems can be said to be an investment for the company, so why is it essential to identify whether the information system used meets the objectives of the organization (DeLone \& McLean, 2016). Therefore it is essential to assess whether the information system applied to the company is appropriate and can provide more benefits for the company. One model used to assess the success of an information system is the DeLone and McLean Information System Success Models.

The use of the D\&M IS Success Model in this study because more than 12,900 research articles have quoted this model. That shows that this model can be used as a reference for evaluating information system implementation. DeLone and McLean research the private sector, namely the banking sector, while in the public sector, there is still not much research done on this DeLone and McLean model. Tan \& Aliyah (2015) stated that a study on testing the DeLone and McLean models conducted in the public sector produced different results and showed a gap in research. Some researchers prove that the DeLone and McLean model has a significant impact and can measure the success of an information system (Almutairi \& Subramanian, 2005b; Khayun, Ractham, \& 
Firpo, 2012; Novianto, 2013; Saleh, Taufik; Darwanis; Bakar, 2012; Wahyuni, 2011). The results of other studies are not all influential variables in the success of information systems (Arifiantika, 2015; Tan \& Aliyah, 2015; Wang \& Liao, 2008).

Information System Implementation in public sector organizations is different from the private sector. The government is one of the public sector organizations that use information systems different from the private sector. The government, in addition to focusing on efficiency, quality, and fairness, the government must also combine with public accountability and trust (Hefetz \& Warner, 2004). The difference between the application of information technology in the private sector with the public sector is that of law, and political influence is higher in the organization of the public sector. The oversight of its implementation is significant because it involves the public (Rocheleau, 2011). Almost every government agency uses an information system. According to Presidential Instruction of the Republic of Indonesia No. 3 of 2003 concerning National Policy and Strategy for EGovernment Development considers.: The use of information technology with systems or activities will become an information system that increases the efficiency, effectiveness, transparency, and accountability of government management, and to conduct good governance. Based on the results of research conducted by Anggriawan \& Yudianto (2018), making decisions on the making and presentation of financial statements can use the information technology used. Therefore, use information technology in the presentation of financial statements in the public sector related to financial management.

The implementation of development carried out by the government as an agency that formulates and manages the National Budget (APBN) requires the government to be responsible and open about its implementation(UU RI No. 25, 2004). One form of responsibility is with a report on financial management. There is an obligation to carry out accountability to the public. The government is required to produce evidence of its accountability to the public in the form of information, one of which is present in financial statements (Mardiasmo, 2009). As a form of government accountability to the public in the preparation of financial reports, the Ministry of
Home Affairs issued a system, namely the Regional Financial Management Information System (SIPKD). SIPKD is an information system that is used to assist local governments in improving the efficiency and effectiveness of the application of rules in terms of regional financial management based on economic, effective, accountable, efficient, and transparency principles (Kemendagri, 2010).

The application of information systems regarding financial management is still considered a problem. The use of information systems is considered to have not reached the goal of why the formation of such information systems, including the following.: in a study from the Directorate General of Fiscal Balance (DJPK), Budiriyanto (2013) states that the development of an information system used in financial management becomes difficult. Differences in rules between central and regional levels which makes it challenging to consolidate between central and regional financial management. Inconsistency of laws regarding who gives authority to regulate regional financial management. Government Regulation (PP) No. 56/2004 article 9 paragraph (1) explains that the Minister of Finance implements the Regional Financial Information System (SIKD). According to PP No. 58/2005, article 155 states that further provisions regarding financial management regulations are regulated continued by the Ministry of Home Affairs. The same PP in section 151 paragraph $(1 \& 2)$ explained that the main points of regional financial management are also regulated in their respective regional regulations. From the explanation above, so there is an inconsistency regarding who has the authority to regulate regional financial management.

Based on the study by Budiriyanto (2013), there is a further problem, namely, regarding the Financial Information System that is used by local governments throughout Indonesia is still diverse. Data reported from DGT by Halim, Jaya, \& Azis (2012), from 524 local governments (LGs), 223 local governments used the Regional Management Information System (SIMDA) application. 68 LG's used the SIPKD application, 123 LGs used other systems, and 110 local governments do not use information systems. Reporting from the Examination Results of the Supreme Audit Board (BPK, 2016, 2017, 2018) states that inadequate accounting and reporting 
information systems occur in several local governments in 2016 there were 291 local governments and 445 findings, in 2017 there were 241 local governments and 351 findings. In 2018 there were 206 local government and 304 findings regarding inadequate accounting and reporting information systems. In IHPS I in 2017 there were weaknesses in the accounting information system and other reporting including the delay in the submission of local government reports, human resources have not entirely been able to support reporting and other problems related to weaknesses in the accounting and reporting control system.

This research was carried out in the Sumedang district government. The selection of research objects in the SIPKD in Sumedang Regency is based on the achievements of the Sumedang District Government that succeeded in obtaining the Unqualified opinion five times in a row (2014-2018) on the Sumedang Regency Regional Government Financial Report (LKPD). This opinion achievement illustrates the successful implementation of the Regional Financial Management Information System (SIPKD) in the Sumedang Regency Government. Hence, researchers need to study the application of SIPKD in Sumedang Regency to become a pilot for other districts or cities.

This study is a replication of the study by Tan \& Aliyah (2015). The difference with previous research is that this study does not use the variable "use"; the data analysis methods used are different indicators. Respondents used are not only SIPKD operators but rather add leaders as users of the information generated by SIPKD so that they can provide a more real condition of the benefits obtained by the agency from the application of the information system. From the explanation above, it motivates the writer to study more deeply the application of SIPKD to the Sumedang District Government using the D\&M IS Success Model.

\section{Literature Review and Hypothesis Development}

Contingency Theory

According to Otley (1978), factors originating from within (internal force) and factors arising from the outside (external force) are two combinations that can affect a person's behavior. Someone's satisfaction in using information systems is caused by two factors that affect, namely internal and external, both of these factors can support a person to use the system continuously to help his work so that the impact on improving performance.

\section{Information Systems Success Model}

The DeLone and McLean models use six measurements of information system success, namely system quality, information quality, service quality, use, user satisfaction, net benefits (DeLone \& McLean, 2016). Following is an explanation of the variables used in the DeLone and McLean Models:

a. System Quality, Systems that have characteristics following the objectives of the use of the system. In this study, the quality of the system is used to assess how the characteristics of SIPKD. Whether it is following the objectives of making SIPKD.

b. Quality Information, Quality information is information that, if generated, has characteristics that are considered necessary by the user. In this study, the quality of information means the quality of information produced - namely financial statements, whether it is following what is needed by users of that information.

c. Service Quality, How is the quality of support from system providers to users of the system. In this research, service quality is how the services provided by the Ministry of Home Affairs as SIPKD providers to SIPKD users.

d. Use, Use of the system by the user. In this study, researchers did not use the use variable because Sumedang District is included in the regional government, which is required to use the Regional Financial Management Information System (SIPKD) based on Letter no. SE. 900 / 360 / BAKD.

e. User satisfaction, the response given by the user after using the information system. In this study, user satisfaction is reflected by operators as system users and leaders as users of the information generated by SIPKD.

f. Net Benefit, results from the use of information systems that contribute to individuals, groups, and organizations - in 
this study, measuring whether the overall SIPKD provides benefits for its application.

\section{Regional Financial Management Information System (SIPKD)}

This SIPKD is an information system that is used to assist local governments in improving the efficiency and effectiveness of the application of rules in terms of regional financial management based on economic, effective, accountable, efficient, and transparency principles (Kemendagri, 2010). SIPKD is also an embodiment of the facilities provided by the Ministry of Home Affairs to local governments related to the area of regional financial management and aims to equalize views on regulations and procedures in financial management (Kemendagri, 2010).

\section{System Quality and User Satisfaction}

To measure the success of information, DeLone and McLean focus on system quality, information quality, and service quality. System quality is defined as the system characteristics desired by the user (DeLone \& McLean, 2016). The use of the system as supporting user performance focuses on what the user wants to achieve. The quality of information systems that are owned can reflect user satisfaction (Guimaraes, Igbaria, \& Lu, 1992; Guimaraes, Yoon, \& O’Neal, 2010). If an information system in an organization is useful, then the users of the system will always use the system and find it helpful in their work so that users feel satisfied with the system. It can show that a sound quality system will give satisfaction to the user.

Hypothesis 1: The quality of the system influences user satisfaction, the higher the quality of the system, the higher the satisfaction of users.

\section{Information Quality and User Satisfaction}

If information can be understood and used by users, it can be said that the information is useful (Suwardjono, 2016). Information produced by an information system will be helpful if the information can be useful and understood by users of the information. Quality information can be used as a reference for making appropriate decisions so that information can provide public confidence in the organization. The higher the quality of information produced by a system will increasingly increase user satisfaction (DeLone $\&$ McLean, 1992). If the information system user assumes that the quality of the information presented is right, then the information produced will be understood and used. The use of this information makes users feel satisfied. So quality information can be used by users will increase user satisfaction.

Hypothesis 2: The quality of information influences user satisfaction, the higher the quality of information, the higher the satisfaction of users.

\section{Service Quality and User Satisfaction}

Services are perceived as services provided by information system providers. Service quality is a comparison between customer expectations and service provider perceptions of services provided (Parasuraman, A., Zeithaml, V., Berry, 1988). User satisfaction over the use of information systems can be reflected in the quality of services provided by service providers (DeLone \& McLean, 2003). If the system users feel that the quality of service offered by the service provider is good, then they will contact satisfied using the system. Therefore the higher the quality of services provided will affect the higher level of user satisfaction.

Hypothesis 3: User satisfaction is influenced by service quality, the higher the service quality, the higher the user satisfaction.

\section{User Satisfaction and Net Benefits}

The most significant measure of success in designing and using is the final result obtained. User response to the use of information system output is called user satisfaction, with user satisfaction in using the system will lead to net benefits received (DeLone \& McLean, 1992). If the user feels satisfied because using the information system means the user believes that the information system provides benefits to them (Wang \& Liao, 2008). The use of a quality information system will give satisfaction to the user, so 
users can receive the benefits of using the system.

Hypothesis 4: Net benefits are influenced by user satisfaction, the higher the user satisfaction, the higher the net benefits.

Hypothesis 5: System quality, information quality, and service quality affect user satisfaction and their implications for net benefits.

\section{Methods}

This study uses system quality, information quality, and service quality as independent variables (X), user satisfaction as intervening variables $(\mathrm{Y})$, and net benefits as dependent variables $(\mathrm{Z})$. With the following indicators:

Table 1. Measurement

\begin{tabular}{|c|c|c|}
\hline Variable & Indicators & Adapted from \\
\hline System Quality $\left(\mathrm{X}_{1}\right)$ & $\begin{array}{ll}\text { - } & \text { Easy to Learning } \\
\text { - } & \text { Easy to Use } \\
\text { - } & \text { Availability } \\
\text { - } & \text { Response Time } \\
\text { - } & \text { System Reliability } \\
\text { - } & \text { Flexibility } \\
\text { - } & \text { Personalizability } \\
\text { - } & \text { System Interactivity } \\
\text { - } & \text { System Security }\end{array}$ & (DeLone \& McLean, 2016) \\
\hline Information Quality $\left(\mathrm{X}_{2}\right)$ & $\begin{array}{l}\text { - } \text { Relevance } \\
\text { - Usefulness } \\
\text { - Understandability } \\
\text { - Accuracy } \\
\text { - Reliability } \\
\text { - Currently } \\
\text { - Completeness } \\
\text { - Timeliness }\end{array}$ & (DeLone \& McLean, 2016) \\
\hline Service Quality $\left(\mathrm{X}_{3}\right)$ & $\begin{array}{ll}\text { - } & \text { Reliability } \\
\text { - } & \text { Empathy } \\
\text { - } & \text { Responsiveness } \\
\text { - } & \text { Contact } \\
\text { - } & \text { Interactivity }\end{array}$ & (DeLone \& McLean, 2016) \\
\hline User satisfaction $(\mathrm{Y})$ & $\begin{array}{l}\text { - } \text { Content } \\
\text { - Accuracy } \\
\text { - Format } \\
\text { - Ease of use } \\
\text { - Timeliness }\end{array}$ & (DeLone \& McLean, 2016) \\
\hline User satisfaction $(\mathrm{Y})$ & $\begin{array}{ll}\text { - } & \text { Content } \\
\text { - } & \text { Accuracy } \\
\text { - } & \text { Format } \\
\text { - } & \text { Ease of use } \\
\text { - } & \text { Timeliness }\end{array}$ & $\begin{array}{l}\text { DeLone \& McLean, 2016; Doll } \\
\text { \& Torkzadeh, 1998) }\end{array}$ \\
\hline & $\begin{array}{ll}\text { - } & \text { Cost } \\
\text { - } & \text { Time } \\
\text { - } & \text { Communication }\end{array}$ & \\
\hline
\end{tabular}




\begin{tabular}{|c|c|c|}
\hline Net Benefit (Z) & $\begin{array}{ll}\text { - } & \text { Avoid Personal Interaction } \\
\text { - } & \text { Control } \\
\text { - } & \text { Convenience } \\
\text { - } & \text { Personalization } \\
\text { - } & \text { Trust } \\
\text { - } & \text { Well-informedness } \\
\text { - } & \text { Participate in decision-making }\end{array}$ & $\begin{array}{l}\text { (Murray, DeLone, \& Golden, } \\
\text { 2009) }\end{array}$ \\
\hline
\end{tabular}

This research was conducted in the Regional Work Unit (SKPD) of the Sumedang District Government with 29 SKPD plus one administrator of the SIPKD Regency. Sumedang selected using purposive sampling. The criteria determined by researchers are SKPD using the SIPKD application. So the sample in this study was 30 samples consisting of 29 SKPD and one administrator. The data used in this study are primary data obtained through the distribution of questionnaires to research respondents. Respondents in this study were SIPKD operators led by agencies and SIPKD administrators. The questionnaire consisted of 38 questions with details of 11 questions regarding net benefits, nine questions about system quality, eight questions about information quality, five questions about service quality, and five questions about user satisfaction - the questionnaire distributed as many as 30 pairs of questionnaires following the research sample. Where for variable questionnaire questions $\mathrm{X} 1, \mathrm{X} 3$, and $\mathrm{Y}$ were filled out by SIPKD operators, agency leaders filled X2 and Z. The SIPKD administrator fills all questionnaires. Respondents in filling out this questionnaire were in accordance with what they felt directly about each variable. The analytical method used in this study is path analysis, with the equation of the research model depicted in Image 1 as follows:

Image 1. Research Model

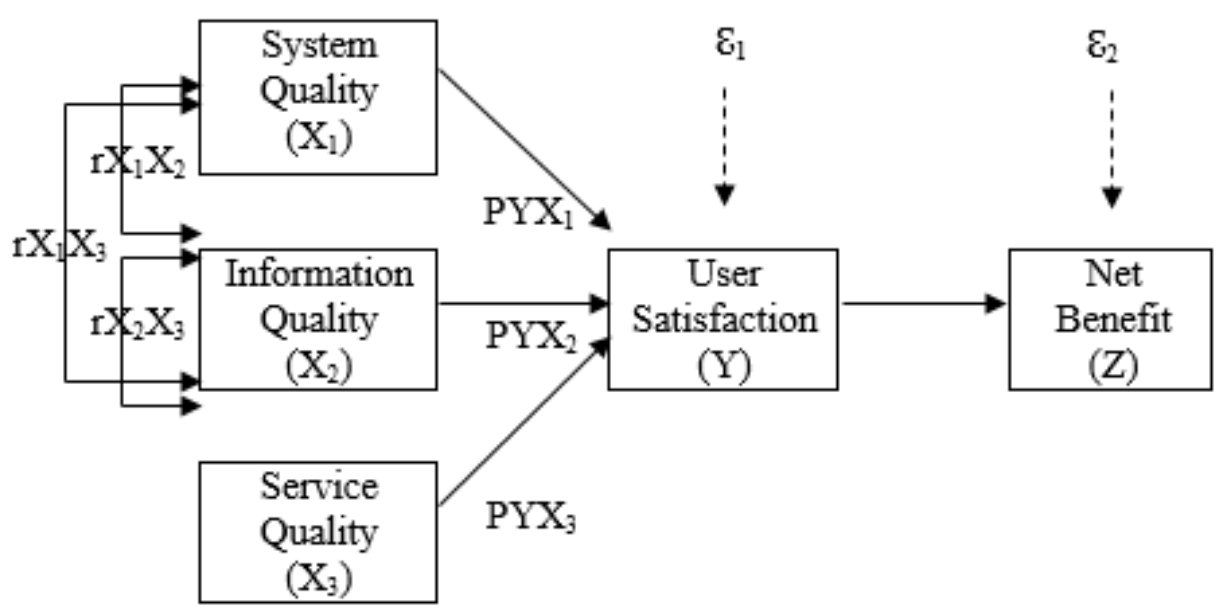

First sub-structure:

$\mathrm{Y}=\rho \mathrm{XX} 1+\rho \mathrm{X} 2+\rho \mathrm{XX} 3+\varepsilon 1$

Second sub-structure:

$Z=\rho z X 1+\rho z X 2+\rho z X 3+\rho Z Y+\varepsilon 2$

\section{Results}

The results of distributing questionnaires to respondents, the characteristics of respondents can be grouped as follows: 
Table 2. Characteristics of Respondents

\begin{tabular}{llc}
\hline \multicolumn{1}{c}{ Criteria } & \multicolumn{1}{c}{ Description } & Number of Respondents \\
\hline Position & SIPKD Operators & 29 \\
& SIPKD Admin & 1 \\
& Head of Division & 11 \\
& Head of Subdivision & 18 \\
Long Served & 1 year & 12 \\
& $1-3$ years & 27 \\
& $>3$ years & 20 \\
Education & Diploma & 1 \\
& Bachelor & 41 \\
& Master & 16 \\
& Others & 1 \\
\hline
\end{tabular}

Descriptive analysis is done to describe the data of each variable studied. Based on table 2., system quality, information quality, service quality, and net benefits are considered very good, while user satisfaction has a good category.

Table 3. Descriptive Analysis

\begin{tabular}{lll}
\hline Variable & Total Score & Category \\
\hline System Quality & 1213 & $\begin{array}{l}\text { Very good } \\
\text { (Interval score 1134-1350) }\end{array}$ \\
Information Quality & 1116 & $\begin{array}{l}\text { Very good } \\
\text { (Interval score 1008-1200) }\end{array}$ \\
Service Quality & 577 & $\begin{array}{l}\text { Well } \\
\text { (Interval score 510-630) }\end{array}$ \\
User Satisfaction & 652 & $\begin{array}{l}\text { Very good } \\
\text { (Interval score 630-750) }\end{array}$ \\
Net Benefit & 1558 & $\begin{array}{l}\text { Very good } \\
\text { (Interval score 1386-1650) }\end{array}$ \\
\hline
\end{tabular}

Source: Data processed, 2019

The results of the descriptive analysis of the system quality variables explain that the quality of SIPKD in Sumedang Regency is considered very good. Availability, system security, system interactivity, and system reliability in SIPKD get the highest score that means this system provides convenience in helping users work because it can be used anywhere and anytime and has a perfect security system. The quality of information produced by SIPKD is outstanding. The information generated is considered relevant and has uses according to the needs of agencies; besides, the information created is very accurate and complete so that it is considered to meet the characteristics of quality information. The quality of services provided by the interior ministry to SIPKD users is considered excellent. The facilities provided are considered good, such as the provision of other supporting needs in SIPKD implementation and care in the form of services when using SIPKD. The response time of service providers if there are problems in the process of using SIPKD is considered not too fast.

User satisfaction felt by users is considered very good. User satisfaction is reflected in the satisfaction with the use of the system, which is considered to provide convenience in completing work. The appearance of the system is also considered to provide convenience and comfort in doing work. The net benefits obtained from the use of SIPKD are felt to be very good. SIPKD provides information on government policies regarding financial reporting, can display information according to agency needs, and 
facilitate communication between local governments and the central government.

Path Analysis

Before testing the causal model with path analysis, there is a significant correlation between the variables that are related and related to each other. The correlation coefficient between research variables can be obtained by processing research data using SPSS, and the result is that all correlation coefficient values are significant at $\alpha=0.05$.

Table 4. Correlation Coefficient Matrix between Variables

\begin{tabular}{|c|c|c|c|c|c|}
\hline & Net Benefit & $\begin{array}{c}\text { User } \\
\text { Satisfaction }\end{array}$ & $\begin{array}{l}\text { System } \\
\text { Quality }\end{array}$ & $\begin{array}{c}\text { Information } \\
\text { Quality }\end{array}$ & $\begin{array}{l}\text { Service } \\
\text { Quality }\end{array}$ \\
\hline Net Benefit & 1 & 0,873 & 0,670 & 0,800 & 0,587 \\
\hline $\begin{array}{c}\text { User } \\
\text { Satisfaction }\end{array}$ & 0,873 & 1 & 0,653 & 0,726 & 0,561 \\
\hline $\begin{array}{l}\text { System } \\
\text { Quality }\end{array}$ & 0,670 & 0,653 & 1 & 0,526 & 0,165 \\
\hline $\begin{array}{l}\text { Information } \\
\text { Quality }\end{array}$ & 0,800 & 0,726 & 0,526 & 1 & 0,380 \\
\hline $\begin{array}{l}\text { Service } \\
\text { Quality }\end{array}$ & 0,587 & 0,561 & 0,165 & 0,380 & 1 \\
\hline
\end{tabular}

Source: Data processed, 2019

Based on the information in table 3 above, it can; besides that system quality, information quality, and service quality have a strong correlation coefficient with user satisfaction (0.60-0.799). Thus, user satisfaction is highly dependent on system quality, information quality, and service quality. Then user satisfaction has a very strong correlation coefficient with net benefits $(0.80$ 1,000). Thus, the net benefit is highly dependent on user satisfaction. Relationships (correlations) that are meaningful or significant between research variables do not conclude a causal relationship occurs between these variables. The relationship structure in the path diagram above will be divided into two models, namely: Sub-structure 1, which links the system quality variables (X1), information quality (X2), service quality (X3), and user satisfaction (Y). Sub-structure 2, which connects the system quality variables (X1), information quality $(\mathrm{X} 2)$, service quality $(\mathrm{X} 3)$, user satisfaction $(\mathrm{Y})$, and net benefits $(\mathrm{Z})$.

Table 5. Summary of Sub-structural 1 Path Coefficient Results

\begin{tabular}{lcclcc}
\hline $\begin{array}{l}\text { Influence } \\
\text { Between } \\
\text { Variables }\end{array}$ & $\begin{array}{c}\text { Path } \\
\text { coefficient } \\
\text { (Beta) }\end{array}$ & $\begin{array}{c}\text { Sig. } \\
\text { Value }\end{array}$ & Test Result & $\begin{array}{c}\text { Determinant } \\
\text { Coefficient }\end{array}$ & $\begin{array}{c}\text { Other } \\
\text { Variable } \\
\text { Coefficients }\end{array}$ \\
\hline X1 consering Y & 0,391 & 0,003 & Significant & $0,733=73,3 \%$ & 0,517 \\
X2 consering Y & 0,388 & 0,005 & Significant & & \\
X3 concering Y & 0,349 & 0,004 & Significant & & \\
\hline
\end{tabular}

Source: Data processed, 2019

The structural equation for sub-structure 1 can be obtained as follows:

$$
\begin{aligned}
& \mathrm{Y}=\rho \mathrm{yX} 1+\rho \mathrm{X} 2+\rho \mathrm{XX} 3+\varepsilon 1 \\
& \mathrm{Y}=0.391 \mathrm{X} 1+0.388 \mathrm{X} 2+0.349 \mathrm{X} 3+0.517 \\
& \mathrm{R}^{2}=0.733
\end{aligned}
$$


Table 6. Summary of Sub-structural 2 Path Coefficient Results

\begin{tabular}{lcclcc}
\hline $\begin{array}{l}\text { Influence } \\
\text { Between } \\
\text { Variables }\end{array}$ & $\begin{array}{c}\text { Path } \\
\text { coefficient } \\
\text { (Beta) }\end{array}$ & $\begin{array}{c}\text { Sig. } \\
\text { Value }\end{array}$ & Test Result & $\begin{array}{c}\text { Determinant } \\
\text { Coefficient }\end{array}$ & $\begin{array}{c}\text { Other } \\
\text { Variable } \\
\text { Coefficients }\end{array}$ \\
\hline $\mathrm{X} 1$ concering Z & 0,220 & 0,044 & Significant & $0,862=86,2 \%$ & 0,371 \\
$\mathrm{X} 2$ concering Z & 0,340 & 0,004 & Significant & & \\
$\mathrm{X} 3$ concering Z & 0,221 & 0,028 & Significant & & \\
Y concering Z & 0,359 & 0,020 & Significant & & \\
\hline
\end{tabular}

Source: Data processed, 2019

The structural equation for sub-structure 2 can be obtained as follows:

$Z=\rho z X 1+\rho z X 2+\rho z X 3+\rho Z Y+\varepsilon 2$

$$
\begin{aligned}
& Z=0,220 X 1+0,340 X 2+0,221 X 3+0,359 \\
& Y+0,371 \varepsilon 2 \\
& R^{2}=0.862
\end{aligned}
$$

Figure 2. Path Diagram of the Research structure

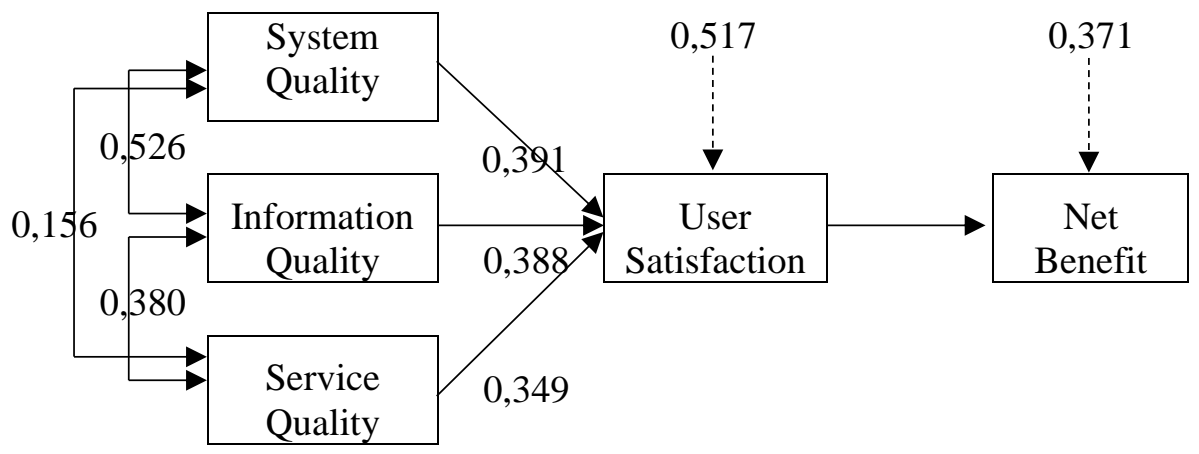

Hypothesis 1, "Quality of the system (X1) has a positive and significant effect on User Satisfaction (Y)" accepted. The quality of the system contributes $0.391^{2} \times 100 \%=15.3 \%$ and is significant for User Satisfaction.

Hypothesis 2, "Quality of information (X2) influences User Satisfaction (Y)" is accepted. The direct effect of information quality is $0.388^{2} \times 100 \%=15 \%$ and significant on User Satisfaction.

Hypothesis 3, "Service quality (X3) influences User Satisfaction (Y)" is accepted. The direct effect of service quality is $0.349^{2} \times 100 \%=$ $12.2 \%$ and significant on User Satisfaction.

Hypothesis 4, "User Satisfaction (Y) has a positive and significant effect on Net Benefits
(Z)" received. The effect of User Satisfaction is $0.359^{2} \times 100 \%=12.9 \%$ and is significant towards Net Benefits.

Hypothesis 5, "Quality of the system (X1), quality of information (X2), quality of service (X3) of user satisfaction (Y), and the implication of net benefits (Z)" are accepted. The results obtained that simultaneously (overall) and individually for each variable X1, $\mathrm{X} 2, \mathrm{X} 3$, and $\mathrm{Y}$ significantly contributed to the variable $\mathrm{Z}$. Based on the findings in this study, the direct influence of system quality, information quality, service quality, and User Satisfaction can be affecting Net Benefits of $0.928 \times 100 \%=86.2 \%$. 


\section{Discussion}

The system quality variable has a significant influence on user satisfaction. In words, hypothesis 1 is accepted. The results of this study are in line with research Almutairi \& Subramanian, (2005a); Khayun et al., (2012); Saleh, Taufik; Darwanis; Bakar, (2012); Wang \& Liao, (2008) which state that system quality is influences user satisfaction. The quality of SIPKD gives satisfaction to the users of this system. Therefore this system is considered to have characteristics that are in accordance with the purpose of its manufacture. The purpose of making SIPKD is to provide information on budgets and realization that makes it easy to disseminate the information so that it makes it easier to control and obtain information. By using this system, the work done becomes more manageable so that it increases user satisfaction.

Information quality has a significant influence on user satisfaction. In other words, Hypothesis 1 is accepted. The results of this study are consistent with the research (Saleh, Taufik; Darwanis; Bakar, 2012; Wang \& Liao, 2008) which states that information quality influences user satisfaction. Based on the results of this study, it means that the information generated by SIPKD has criteria according to the wishes of the information useful so that the user can feel satisfied with the data generated. The information generated in the form of financial statements. Following the results of the BPK audit of the financial statements of the Sumedang District Government which received an unqualified opinion, can be interpreted by the use of SIPKD as an application that helps financial management can provide good results in terms of financial management.

Service quality has a significant effect on user satisfaction. In other words, hypothesis 3 is accepted. The results of this study are in line with research (Khayun et al., 2012) which states that service quality affects user satisfaction. The Ministry of Home Affairs as a SIPKD service provider, not only provides the system but also includes training in the use of the system, attention if there are problems, and other services provided so that it can increase user satisfaction. Service providers not only provide the system but also provide after-sales service so that users feel satisfied using the system.

User satisfaction affects net benefits. In other words, hypothesis 4 is accepted. The results of this study are in line with research ((Tan \& Aliyah, 2015; Wang \& Liao, 2008) which states that user satisfaction influences net benefits. It means that SKPD as SIPKD users feel satisfied using this system. That's indicated by the net benefits obtained by the agency. The most significant net benefit is felt by the SKPD of Sumedang Regency, which concerns communication, personalization, and wellinformedness.

The quality of the system, the quality of information, and the quality of service affect user satisfaction and have implications for net benefits. In other words, hypothesis 5 is accepted. From the explanation above states that the implementation of SIPKD in Sumedang district was considered successful. SIPKD can give satisfaction to users (reflected by the quality of the system, the quality of information and the quality of services) and the net benefit obtained by the agency, namely the Sumedang district in general.

\section{Conclusion}

System Quality, Information Quality, and Service Quality have increased so that User Satisfaction has also increased so that it will also have an impact on improving the SIPKD Net Benefits in the Sumedang District Work Unit. That means that the better the system is defined from the quality of the system, the quality of information produced, and the quality of services provided by the application provider can increase the satisfaction of the system user, with user satisfaction resulting in benefits derived from the use of the system. That shows that the implementation of SIPKD in the Sumedang Regency was considered successful because it could provide benefits for Sumedang Regency. Regencies/cities that have not implemented SIPKD are expected to consider 
using this system. Because they are considered to have many benefits and can help facilitate the management of regional financial reports so that they have a uniform format and results in the preparation of regional financial reports. The limitation of this research is that it only reviews from the user side of the information system. The results of this study can be followed up by adding information from other parties, such as the interior ministry as a SIPKD service provider.

\section{References}

Almutairi, H., \& Subramanian, G. H. (2005a). An empirical application of Delone and Mclean model the Kuwaiti private sector. Journal of Computer Information System. https://doi.org/10.1080/08874417.2005.1 1645849

Almutairi, H., \& Subramanian, G. H. (2005b). An Empirical Application of The DeLone and McLean Model in The Kuwaiti Private Sector. Journal of Computer Information System, 45(3), 113-122. https://doi.org/http://dx/doi.org/10.1080/ 08874417.2005.11645849

Anggriawan, F. T., \& Yudianto, I. (2018). Factors Affecting Information Quality of Local Government Financial Statement. Journal of Accounting Auditing and Business, 1, 30-42. https://doi.org/https://doi.org/10.24198/ja ab.v1i1.15652

Arifiantika, J. (2015). Analysis of the Success Rate of Implementing Regional Financial Management Information Systems through the DeLone and McLean Model. Jurnal Akuntansi Dan Sistem Teknologi Informasi, 11, 94-101.

BPK. (2016). Summary of First Semester Audit Examination Results (IHPS BPK) in 2016.

BPK. (2017). Summary of First Semester Audit Examination Results (IHPS BPK) in 2017.

BPK. (2018). Summary of First Semester Audit Examination Results (IHPS BPK) in 2018

Budiriyanto, E. (2013). Legal Review of Regional Financial Information Systems
(SIKD).

DeLone, W. H., \& McLean, E. R. (1992). Information systems success: The quest for the dependent variable. Information Systems Research. https://doi.org/10.1287/isre.3.1.60

DeLone, W. H., \& McLean, E. R. (2003). The DeLone and McLean model of information systems success: A ten-year update. Journal of Management Information Systems. https://doi.org/10.1080/07421222.2003.1 1045748

DeLone, W. H., \& McLean, E. R. (2016). Information Systems Success Measurement. Foundations and Trends ${ }^{\circledR}$ in Information Systems. https://doi.org/10.1561/2900000005

Doll, W. J., \& Torkzadeh, G. (1998). Developing a multidimensional measure of system-use in an organizational context. Information and Management. https://doi.org/10.1016/S03787206(98)00028-7

Guimaraes, T., Igbaria, M., \& Lu, M. -t. (1992). The Determinants of DSS Success: An Integrated Model. Decision Sciences. https://doi.org/10.1111/j.15405915.1992.tb00397.x

Guimaraes, T., Yoon, Y., \& O’Neal, Q. (2010). Exploring the factors associated with expert systems success. Gestão \& Produção. https://doi.org/10.1590/s0104530x1997000100001

Halim, A., Jaya, W. K., \& Azis, N. (2012). Legality, Opportunities and Obstacles to Development of State and Regional Financial Information Systems (E-SIKD). Kajian Tim Asistensi Kementerian Keuangan Bidang Desentralisasi Fiskal.

Hefetz, A., \& Warner, M. (2004). Privatization and its reverse: Explaining the dynamics of the government contracting process. Journal of Public Administration Research and Theory. https://doi.org/10.1093/jopart/muh012

Janson, M. A., \& Subramanian, A. (1996). Packaged software: Selection and implementation policies. INFOR. 
https://doi.org/10.1080/03155986.1996.1 1732298

Kemendagri. (2010). SIPKD Implementation Guidelines.

Khayun, V., Ractham, P., \& Firpo, D. (2012). Assessing E-Excise Success with Delone and Mclean's Model. Journal of Computer Information Systems. https://doi.org/10.1080/08874417.2012.1 1645556

Lucas, H. C., Walton, E. J., Ginzberg, M. J., \& Leonard Stern, J. N. (1988). Implementing Packaged Software Packaged Software. Source: MIS Quarterly.

Mardiasmo. (2009). Public Sector Accounting. Yogyakarta: Andi Yogyakarta.

Murray, S., DeLone, W. H., \& Golden, W. (2009). Understanding net benefits: A citizen-based perspective on egovernment success. Thirtieth International Conference on Information Systems.

Novianto, I. (2013). Evaluation of the Success of Implementing a Regional Financial Management Information System (SIPKD) Study in the Government of Yogyakarta City. Universitas Gajah Mada.

Otley, D. T. (1978). Budget Use and Managerial Performance. Journal of Accounting Research. https://doi.org/10.2307/2490414

Parasuraman, A., Zeithaml, V., Berry, L. (1988). SERVQUAL: A Multiple-Item Scale for Measuring Consumer Perceptions of Service Quality. Journal of Retailing.

Rocheleau, B. (2011). Public Management Information Systems. In Public Management Information Systems. https://doi.org/10.4018/978-1-59140807-9

Saleh, Taufik; Darwanis; Bakar, U. (2012). Effect of Information System Quality on Accounting Information Quality in Efforts to Increase Accounting Software User Satisfaction with the Government of
Aceh. Jurnal Akuntansi Pascasarjana Universitas Syiah Kuala, 1.

Suwardjono. (2016). Accounting theory: engineering of financial reporting. In BPFE- Yogyakarta. https://doi.org/2013

Tan, D., \& Aliyah, S. (2015). Testing the success of the Delone \& Mclean model of information systems on the public sector. University Research Colluqoium.

UU RI No. 25 tahun. Law of the Republic of Indonesia Number 25 of 2004 concerning the National Development Planning System. (2004).

Wahyuni, T. (2011). Empirical Test of DeLone and McLean Models for the Success of the Regional Management Information System (SIMDA). Jurnal Badan Pendidikan Dan Pelatihan Keuangan.

Wang, Y. S., \& Liao, Y. W. (2008). Assessing eGovernment systems success: A validation of the DeLone and McLean model of information systems success. Government Information Quarterly. https://doi.org/10.1016/j.giq.2007.06.002 